\title{
The Effect of Windbreak Parameters on the Wind Erosion Risk Assessment in Agricultural Landscape
}

\author{
Josef Kučera ${ }^{*}$, Jana Podhrázská', Petr Karásek'1, Vladimir Papaj² \\ 1 Research Institute for Soil and Water Conservation, v.v.i., Department of Land Consolidations and Landscape \\ Use, Lidická 25/27, 60200 Brno, Czech Republic \\ 2 Research Institute for Soil and Water Conservation, v.v.i., Department of Land Consolidations and Landscape \\ Use, Žabovřeská 250, 15627 Praha, Czech Republic \\ * Corresponding author's e-mail: kucera.josef.jr@vumop.cz
}

\begin{abstract}
The increasing risk of wind erosion in the context of climate change represents a highly pressing issue. This increase is a result of the growing occurrence of droughts and elevated temperatures in the intensively farmed areas. Effective protection against the wind erosion can be provided by windbreaks, especially during the period when the soil is not protected by the vegetation cover of crops. In this report, the authors wanted to compare the methods defining the windbreak protection zones. The optical porosity and the windbreak height were the basic parameters for defining the protection area. The various methods differ among themselves by using the windbreak height parameter or not. The optical porosity of the windbreaks was determined based on photographic documentation. For the comparison, the cadastral area of Micmanice was selected due to the wide network of windbreaks in this locality. A database of windbreak height and optical porosity for each windbreak was set up. Our report thus presents the application of the new knowledge aimed at updating the methods and procedures for assessing the vulnerability of the area by wind erosion. The application of the method involving the optical porosity and windbreak height parameters resulted in a significant reduction of the windbreak protection zone compared to the method omitting the windbreak height.
\end{abstract}

Keywords: climate change, agricultural land, protection zones

\section{INTRODUCTION}

Wind (eolic) erosion is a result of the mechanic activity of wind, which disrupts the soil surface, loosens and removes the soil particles and deposits them in other locations. This event occurs when the wind strength exceeds the threshold value of soil resistance to erosion (Pasák et al., 1984). In intensively managed agricultural land, the surface covered by protective vegetation is gradually reduced, creating the conditions for the occurrence of accelerated erosion (Holý, 1994).

Under the conditions of the Czech Republic, for a certain period, the processes of wind erosion had not attracted particular attention. Wind erosion was perceived as a marginal process compared to water erosion, which affects more than $50 \%$ of agricultural land. The surface of the land at risk of wind erosion was estimated at 10-15\% (Švehlík, 2002).

The process of wind erosion is a result of an entire complex of interactions including the wind speed, precipitation, surface roughness, soil texture and aggregation, agricultural activities, vegetation cover, and land block size (Janeček et al., 2012).

According to their permeability and effectiveness, windbreaks are divided into three principal categories: blow-through (porosity ca. 60\%), semi-blow-through, and non-blow-through (porosity ca. 20\%) (Abel et al. 1997, Janeček et al., 2005). The windbreak structure is determined by both its outer and inner structure. The outer structure is represented by its width, height, shape, and orientation. The inner structure includes the amount and distribution of leaves, branches, 
boughs, and trunks of shrubs or trees (Podhrázská et al., 2011, Kuhns, 2012). Optical porosity (OP) established based on photographs (Kenney, 1987, Guan et al., 2003, Podhrázská et al., 2011, Lampartová et al., 2015) is often used for assessing the windbreak effectiveness.

According to Heisler and DeWalle (1988), windbreaks with low and medium porosity provide much higher effectiveness than those with higher porosity. The low-porosity windbreaks often lead to turbulent flows with higher wind speed on the leeward side compared to the medium-porosity ones (Cornelis et al., 2000). The windbreak effect on decreasing the wind speed has been reported in the range of 20-35-fold windbreak height on the leeward side depending on its optical porosity (Heisler and DeWalle, 1988, Abel et al., 1997, Venézia, 2001, Vigiak et al., 2003, Brandle et al., 2004, Janeček et al., 2012). OP is defined as the proportion of background visible from the direction orthogonal to the windbreak (Burke, 1998).

The presented study reports the evaluation of a windbreak system in an area at risk of wind erosion located in south Moravia (Czech Republic) using various methodological approaches.

\section{METHODOLOGY AND DATA}

\section{Model locality Micmanice}

The model locality is situated south-east from the city of Znojmo. The climate is warm, dry, with mild winters. For reference station, the meteorology station in Kuchařovice near Znojmo was selected. The annual sum of precipitation ranges around $530 \mathrm{~mm}$, with maximum precipitation from June to August (monthly sum around $70 \mathrm{~mm}$ ). The annual temperature average is about $9^{\circ} \mathrm{C}$, with maximum temperatures also reached in the period June-August and ranging around $18^{\circ} \mathrm{C}$. The prevailing orientation of erosionthreatening winds is from southeast and southsoutheast. Rains are usually of short duration, with low precipitation mainly in the early spring months. The soil moisture is additionally reduced by high evaporation. The model locality is part of the Dyje-Svratka basin, with altitude about 200 $\mathrm{m}$ a.s.l. The favourable terrain relief allows intensive agricultural management, with pronounced negative effects on the landscape, where large arable land blocks prevail and give it a monotonous aspect, see Figure 1.

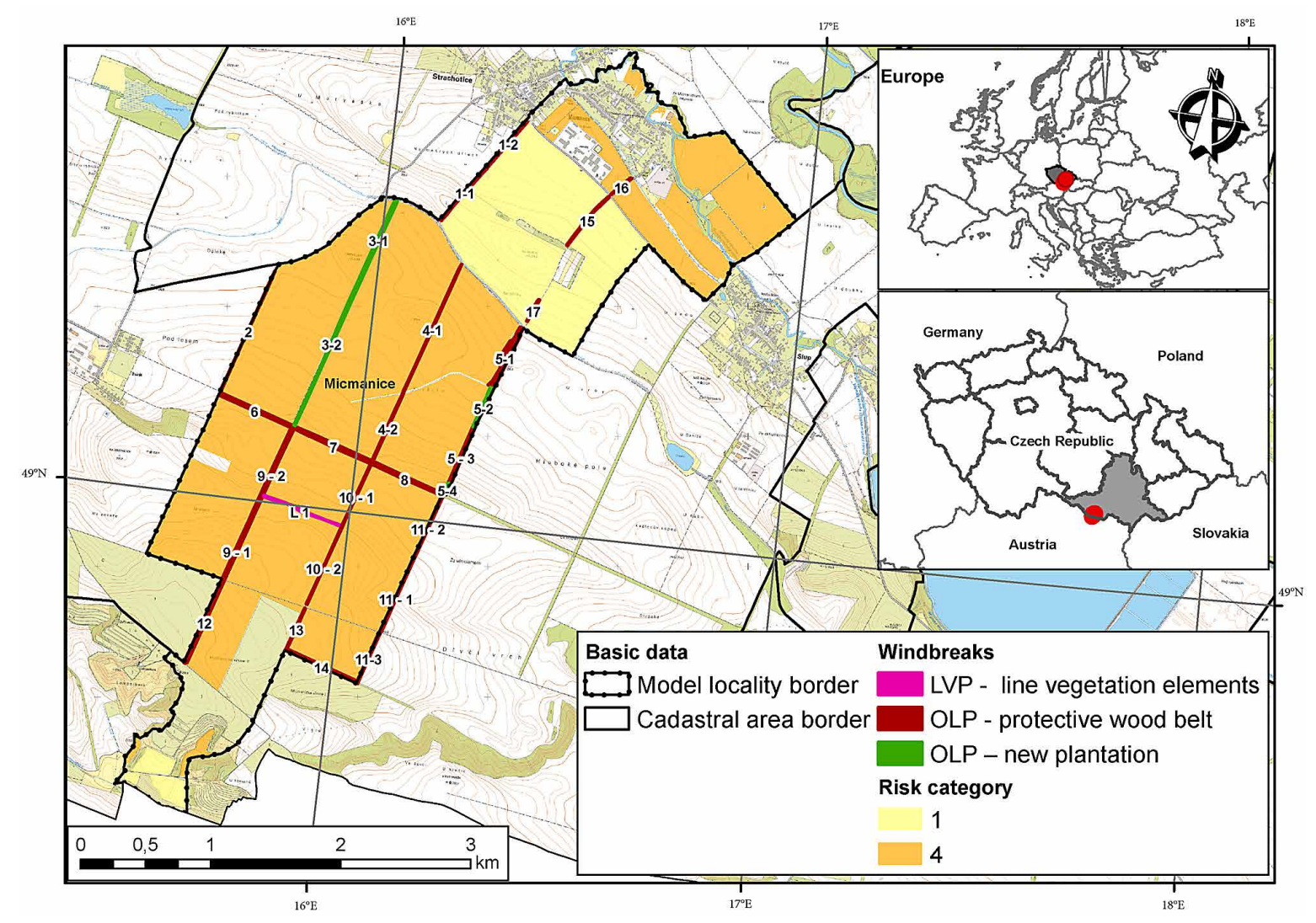

Fig. 1. Survey map of model locality Micmanice (Czech Republic) 
The evaluation was performed in the Micmanice cadastral area. The total assessed surface area of arable land was 816.4 ha. This area includes 664.0 ha of arable land at risk of wind erosion and 152.4 ha of land at no risk. The major part of this cadastral area therefore falls into the category at risk. In this model locality, 26 windbreaks were identified. Out of these, two elements were in the category of line vegetation and 24 elements in the category of protective wood belts. For each windbreak, the OP, height, and width were determined.

The optical porosity was determined based on the photographs taken with a Nikon D3100 digital camera. The date of photographing was selected so that the windbreaks were leafless (March 28, 2017). The photographs were taken in a preselected $30 \mathrm{~m}$ long representative section of the windbreak in a perpendicular axis from a tripod situated $1.6 \mathrm{~m}$ above the ground level. The GIMP (version 2.8.2), ArcGIS for Desktop and Excel programs were used to establish OP. Using available tools, the photographs were graphically adjusted (highlighting vegetation against the background) to create a binary image where the black grid = vegetation, white grid = background . These adjusted photographs were analysed in the ArcGIS settings. The higher the OP value was, the lower the barrier effect of the windbreak. A square grid with 6-7 rows and 12 columns was used to analyse the binary image. The lower row of windbreaks was analysed using the dimensions of $2.5 \times 2.5 \mathrm{~m}$ per grid square (Fig. 2 ). For the upper windbreak row, a more detailed grid was used, i.e., each $2.5 \times 2.5$ m square was further divided into 16 smaller squares. This more detailed analysis of the upper row was used to obtain more accurate definition of the overall OP with taking into account the windbreak height in each assessed column. The squares in the uppermost row with OP 100\% were not included into the overall OP determination to avoid bias of the total windbreak OP value.

The windbreak height was determined using a Suunto Instrument altimeter, and was further corrected based on the digital surface model data (State Administration of Land Surveying and Cadastre).

In order to determine the potential risk of wind erosion, the pedological-climatic factors were used. The data on the soil type vulnerability to wind erosion, short-term drought risk, and risk of occurrence of erosion-producing winds were employed (Podhrázská et al., 2016, Doležal et al., 2017). The area at potential risk was determined for arable land.

The information on the prevailing wind orientation was essential to the analysis. These data were obtained from the Czech Hydrometeorological Institute. Two prevailing wind orientations were identified on their basis (south-east and south-southeast).

Three approaches to protective zone establishment were used for the comparison. The first approach utilized the methodology of Podhrázská et al. (2008), defining the protective zone for windbreaks (protective wood belts) as
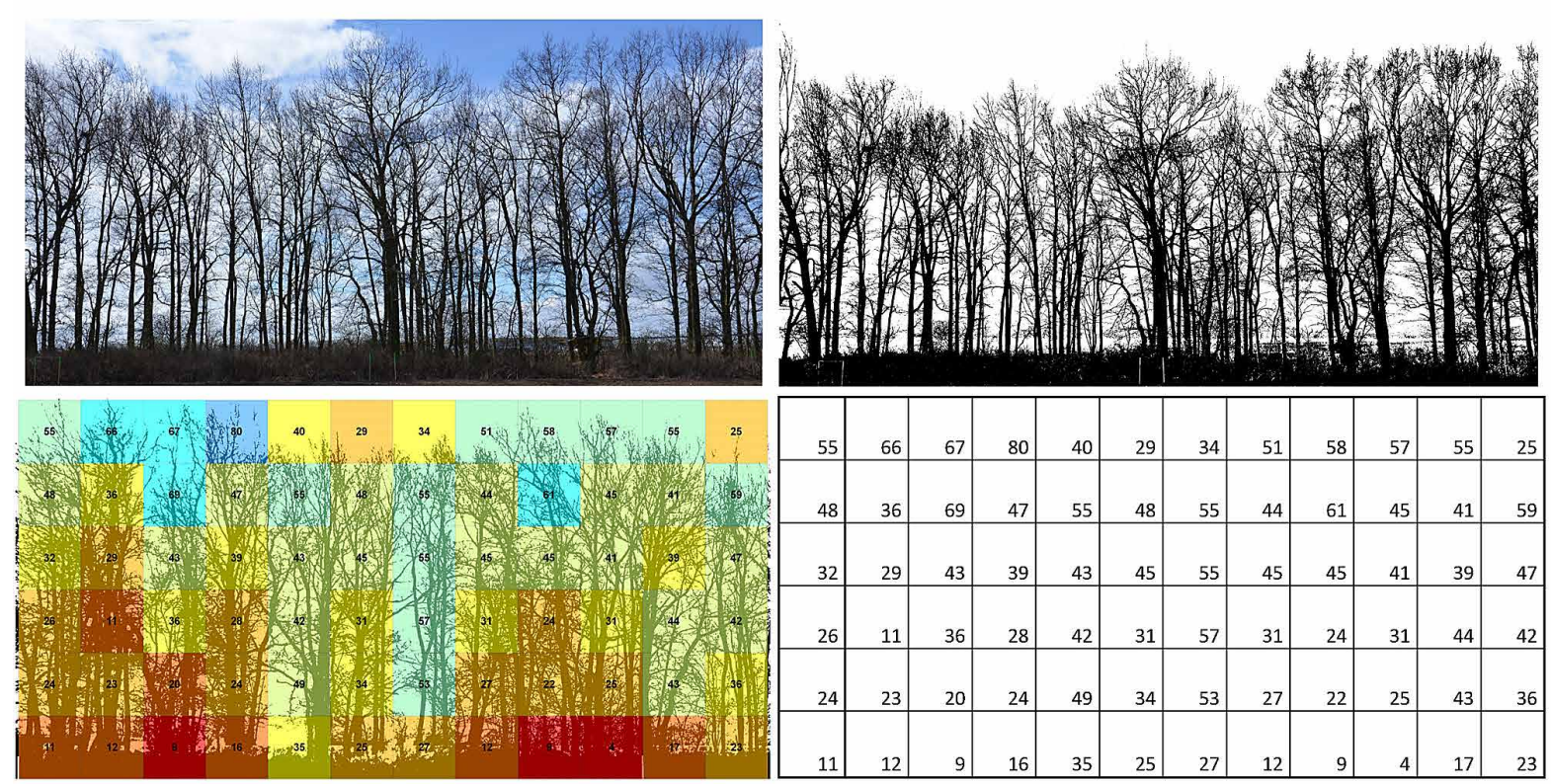

Fig. 2. Modification of photographs and evaluation of optical porosity (in \%) 
a fixed value of $300 \mathrm{~m}$ for the protective zone on the leeward side and $100 \mathrm{~m}$ on the windward side. These values were based on the evaluation of windbreaks with optimal spatial and species distribution, with average height of $15 \mathrm{~m}$. Thus, this approach did not make use of the obtained windbreak parameters (optical porosity and windbreak height).

The second approach involved defining the protective windbreak zone according to the methodology of Doležal et al. (2017). This approach is based on a combined regression equation, establishing the relationship between the optical porosity and weakening of wind speed both on the leeward and windward side. The equation was first presented in Středová et al. (2012). Using this equation, the protective zones were defined based on the evaluated optical porosity (Podhrázská et al., 2011). The optical porosity was used as a parameter, in contrast to the windbreak height, which was not taken into account.

Equation 1: equation for establishing protective zones according to the method of Středová 2012

$$
\begin{aligned}
z= & a \times \exp \left(-\frac{\exp (-(x-b)}{c}\right)-\frac{(x-b)}{(c+1)}+ \\
& +d \times \exp \left(-\frac{(y-f)}{g}\right)-\frac{(y-f)}{g+1}
\end{aligned}
$$

where: $y$-optical porosity (\%)

$$
\begin{aligned}
& \text { Coefficients: } \\
& a=4.1417551362956196 \mathrm{E}+01 ; \\
& b=6.9845535425079362 \mathrm{E}+01 ; \\
& c=8.2090132918982135 \mathrm{E}+01 ; \\
& d=1.0073376683165979 \mathrm{E}+01 ; \\
& \mathrm{f}=2.0979890320903436 \mathrm{E}+01 ; \\
& \mathrm{g}=6.6089573586774133 \mathrm{E}+00
\end{aligned}
$$

The third approach employed both optical porosity and windbreak height as parameters to define the protective zones ( This approach models the protective zones for the leeward side only.

Equation 2: equation for establishing protective zones according to the method of Řeháček 2012

$$
\begin{aligned}
\mathrm{U}= & 52.80619-1.23901 \mathrm{xOP}- \\
& 5.80657 \mathrm{xD}+0.12503 \mathrm{xOPxD}+ \\
& 0.56948 \mathrm{xD}^{2}+0.02507 \mathrm{xOP}^{2}
\end{aligned}
$$

where: $U$ - windbreak effectiveness - reduction of wind speed on the leeward side (\%) $O P$ - optical porosity (\%)
$D$ - distance from the windbreak (fold of windbreak height $\mathrm{H}$ ),

The approaches used in the methodologies of Podhrázská et al. (200) and Středová et al. (2012) contemplate the use of windbreaks with optimum spatial and species distribution, i.e., with fixed expected windbreak height of $15 \mathrm{~m}$. For the optimum comparison of these three approaches to defining the protective zones, the newly planted windbreaks (7 to 8 years of age) were excluded from the analysis. This applied to four elements (3-1, 3-2, 5-2, and 5-4), see Figure 1.

The ArcGIS for Desktop setting and the script created in the PYTHON settings were used to model the protective zones for individual elements. On the basis of the input wind orientation and protective zone length, the script created the actual protective zone.

\section{RESULTS}

By assessing the wind erosion risk rate, it was found that the model locality contained soil at the risk categories 1 (no risk) and 4 (soil at risk). The prevailing risk category in the model locality is 4 , concerning $81 \%$ of arable land. The remaining $19 \%$ fall into category 1 . The authors identified 26 windbreaks in the locality and determined their $\mathrm{OP}$ and plantation height. The protective zones of the windbreaks were defined for the prevailing wind orientations from south-east and southsoutheast. As mentioned in the previous section, protection zones were not created close to the newly planted barriers. Therefore, only 22 barriers were included into the analysis. The height of these windbreaks was in the range between 2 to 3.5 metres. In the fully involved plantations (barriers), the height ranged between 8.7 to 18.2 metres. The OP values of the assessed windbreaks were between $32 \%$ and $58 \%$.

Table 2 shows a summary of the obtained data. The analysed methods of protective zone determination included the data on the prevailing

Table 1. Establishment of protective zones according to the methodology of Podhrázská 2008

\begin{tabular}{|c|c|c|}
\hline Barrier type & $\begin{array}{c}\text { Leeward side } \\
{[\mathrm{m}]}\end{array}$ & $\begin{array}{c}\text { Windward side } \\
{[\mathrm{m}]}\end{array}$ \\
\hline PWB & 300 & 100 \\
\hline Other LVE & 150 & 50 \\
\hline
\end{tabular}


Table 2. Results of analyses establishing protective zones by the described methods

\begin{tabular}{|c|c|c|c|c|}
\hline $\begin{array}{c}\text { Method of protective } \\
\text { zone establishment }\end{array}$ & $\begin{array}{c}\text { Prevailing wind } \\
\text { orientation }\end{array}$ & $\begin{array}{c}\text { Total surface area at } \\
\text { risk [ha] }\end{array}$ & $\begin{array}{c}\text { Total surface area of } \\
\text { protective zone [ha] }\end{array}$ & $\begin{array}{c}\text { Percentage of protective zone } \\
\text { surface area [\%] }\end{array}$ \\
\hline Podhrázská 2008 & SSE & 816.4 & 271.7 & 33.3 \\
\hline Podhrázská 2008 & SE & 816.4 & 306.9 & 37.6 \\
\hline Středová 2012 & SSE & 816.4 & 285.2 & 34.9 \\
\hline Středová 2012 & SE & 816.4 & 320.5 & 39.3 \\
\hline Řeháček 2016 & SSE & 816.4 & 97.8 & 12.0 \\
\hline Řeháček 2016 & SE & 816.4 & 103.6 & 12.7 \\
\hline
\end{tabular}

wind orientation, total surface area of soil at risk (assessed soil), surface area of the defined protective zones, and percentage of the protective zone surface area. Fig. 3 provides map outputs for the analysed methods of defining protective zones for the prevailing south-east wind orientation.

\section{CONCLUSIONS}

The model locality belongs to the areas at high risk of wind erosion. The arable land occupies a total surface area of 816.4 ha. Out of these, $81.0 \%$ fall into the risk category 4 and the remaining $19.0 \%$ into category 1 . According to the first method (Podhrázská et al., 2008), where protective zones were established based on fixed distance values (protective wood belts - leeward 100 $\mathrm{m}$ and windward $300 \mathrm{~m}$, other line vegetation leeward $50 \mathrm{~m}$ and windward $100 \mathrm{~m}$ ), 33.3\% arable land was protected from the SSE-oriented wind and $37.6 \%$ from the SE-oriented wind. According to the second method (Středová et al., 2012) - dependence of the protective zone on optical porosity $-34.9 \%$ arable land was protected from the prevailing SSE wind and 39.3\% from the SE wind. With the last employed method (Řeháček 2016), using optical porosity and plantation height to define the protective zone, the lowest proportion of land was protected compared to the two previous methods. Only $12.0 \%$ of arable land was protected from the SSE-oriented wind and $12.7 \%$ from the prevailing SE wind. While comparing these results, the two approaches of Podhrázská (2008) and Středová (2012) showed similar values, while the method of Řeháček (2016) gave significantly lower percentage of protected arable land compared to the two previous approaches. With the prevailing SE wind orientation, the difference from the values of Podhrázská (2008) was 24.9\% and compared to the method of Středová (2012), the difference was $26.61 \%$. These differences are due to the fact that the method of Řeháček (2016) does not include modelling of the leeward side of the protective zone and takes into account the actual windbreak height (the windbreak height in the model locality was in the range between 8.7 to $18.2 \mathrm{~m})$. In the two previous methods, the protective zones were modelled both on the leeward and windward side and considered the average windbreak height of $15 \mathrm{~m}$.

The risk of wind erosion has become an intensively discussed topic, particularly in association with the occurrence of periods of drought and their growing duration. The South Moravian region, where the model locality is situated, is one of the areas most threatened by the drought occurrence, closely connected with development of erosion processes. Protection of land by means of windbreaks represents one of the oldest means of preventing the wind erosion. This fact was already evident to our ancestors, who planted wood belts in the areas at risk to prevent the wind erosion effects. A particularly significant era for planting windbreaks was the period between the 1950s and 1960s, when after collectivization and unification of land property, extensive networks of protective wood belts had been established. However, with time, these windbreaks had become neglected and were affected by degradation, drying, and growth of invasive species. At present, the efforts to return line greenery to the landscape have returned, particularly via local systems of ecologic stability, planting local biocorridors, and interactive elements implemented, e.g., by land adaptations. However, when considering this problem in South Moravia, one should always keep in mind that these elements should not only serve as landscape-forming elements, but also fulfil the anti-erosive function, and their spatial and functional parameters, along with the species distribution, should be adapted to this purpose. This is also supported by the results of this study, confirming the dependence of the windbreak effectiveness on the woody plant distribution (expressed as OP). 

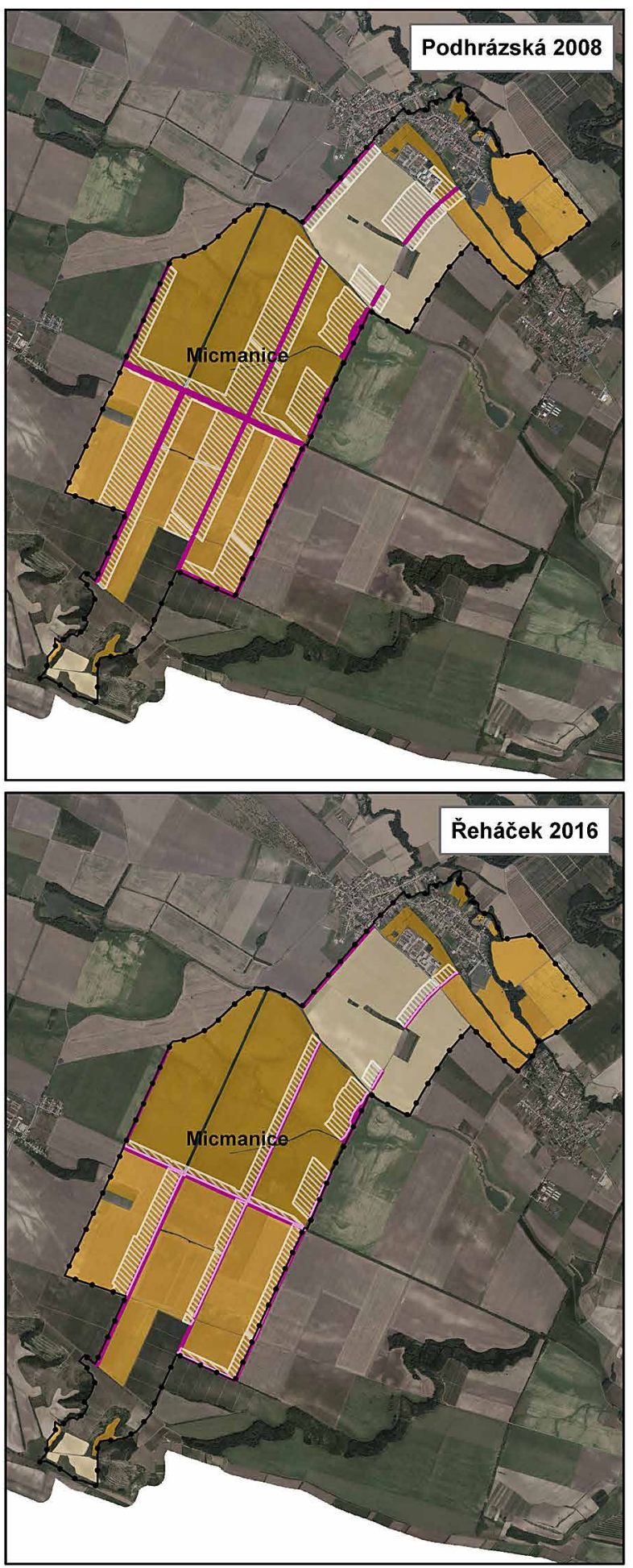

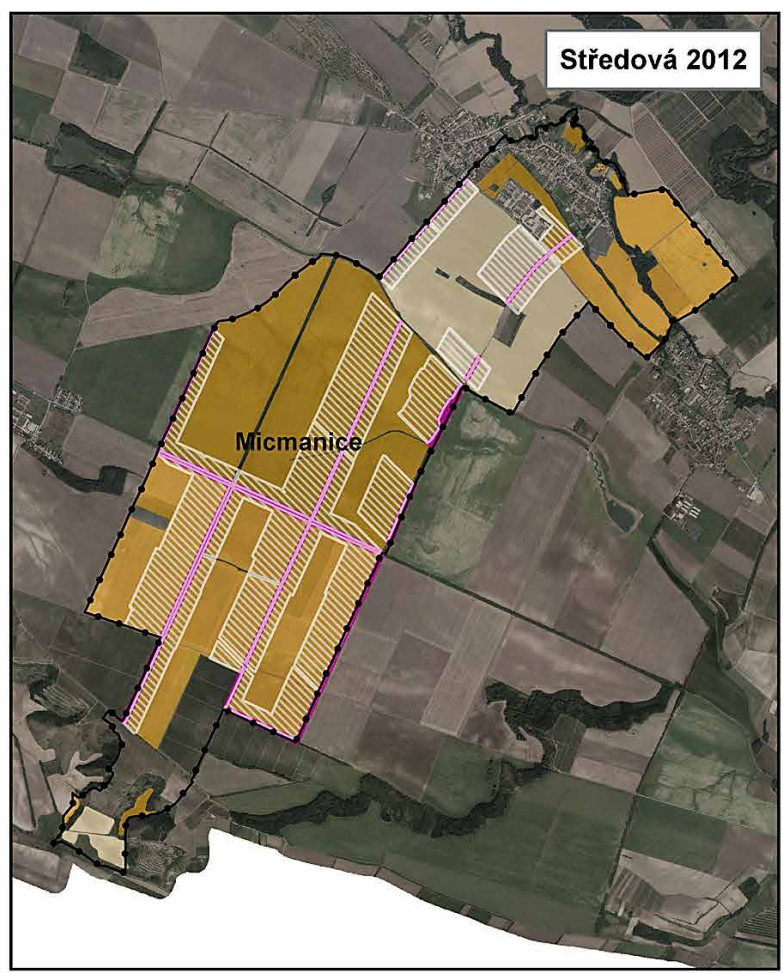

C 3 Cadastral area border

Windbreaks

Protection area

Risk category

1

4 source data:

administrative boundaries: @ ČÚZK 2019

software:

Fig. 3. Example of modelling protective zones for the prevailing south-east wind orientation 


\section{Acknowledgements}

This study was part of projects NAZV QK1710197 supported by the Technology Agency of the Czech Republic and MZE RO2019 supported by the Ministry of Agriculture of the Czech Republic.

\section{REFERENCES}

1. Abel, N., et al., 1997. Design principles for farm forestry: A guide to assist farmers to decide where to place trees and farm plantations on farms. Barton, A. C.T.: Rural Industries Research and Development Corporation, Canberra, 102 pp.

2. Brandle, J.R. et al. 2004. Windbreaks in North American agricultural systems. Agroforestry Systems 61: 65-78

3. Burke, S., 1998. Windbreaks. Inkata Press: Port Melbourne, pp. 128.

4. Doležal, P., Podhrázská, J., Kučera, J., Středová, H., Středa, T., Doubrava, D., 2017. Management of Wind Erosion Risk. Certified Methodology. Brno: Research Institute for Soil and Water Conservation, v.v.i. Certification organ: SPU, Certificate No.: 2/2017 SPU/O (in Czech).

5. Guan, D., Zhang, Y., \& Zhu, T., 2003. A wind-tunnel study of windbreak drag. Agricultural and Forest Meteorology, 118 (1-2), 75-84.

6. Heisler, G.M. a DeWalle, D.R., 1988. Effects of windbreak structure on wind flow. Agric. Eco-systems Environ., 22/23: 41-69.

7. Holý, M. 1994. Erosion and the Environment, Publishing house of the Czech Technical University, Prague (in Czech),

8. Janeček, M., 2005. Protection of Agricultural Land against Erosion: Methodology. $1^{\text {st }}$ Ed. Prague, pp. 195 (in Czech).

9. Janeček, M., 2012. Protection of Agricultural Land against Erosion: Methodology. $1^{\text {st }}$ Ed. Prague, 113. (in Czech).
10. Kenney, W. A., A., 1987. Method for Estimating Windbreak Porosity Using Digitized Photographic Silhouettes. Agricultural and Forest Meteorology, 39(2-3), 91-94.

11. Kuhns M. 2012. Windbreak Benefits and Design. Rural/Conservation Forestry. Utah Forest Facts. Utah State University, Cooperative Extension, p. 4.

12. Lampartová I., Schneider J., Vyskot I., Rajnoch M., Litschmann T. (2015): Impact of protective shelterbelt microclimate characteristics. Ekológia (Bratislava), 34(2): 101-110.

13. Pasák, V., et al., 1984. Protection of Soil against Erosion. $1^{\text {st }}$ Ed. SZN Prague. 1984. pp. 164 (in Czech).

14. Podhrázská J. et al., 2011. Potential Risk of Wind Erosion in Agricultural Land. Certified Methodology, Research Institute for Soil and Water Conservation, v.v.i. (in Czech).

15. Podhrázská J., et al., 2008. Optimization of Windbreak Functions in Agricultural Landscape. Research Institute for Soil and Water Conservation, v.v.i.: Brno. Ref. No. 17161/08-13070 (in Czech).

16. Podhrázská J., P., Kučera J., Středová H., Středa T., 2016. Map of the Risk of Wind Erosion in Arable Land according to Cadastres. Research Institute for Soil and Water Conservation, v.v.i.: Brno. Certificate No. 1/2017 SPU/O (in Czech).

17. Řeháček et al., 2016. Effect of Windbreaks on Wind Speed Reduction and Soil Protection against Wind Erosion, Soil \&Water Res., 10.17221/45/2016-SWR.

18. Středová H., Podhrázská J., Litschmann T., Středa T., Rožnovský J., 2012. Aerodynamic parameters of windbreak based on its optical porosity. Contributions to Geophysics and Geodesy, 42: 2013-226.

19. Švehlík, R., 2002. Wind erosion in south-east Moravia, Collection of Natural Science Club in Uherské Hradiště (in Czech).

20. Vézina A., 2001. Les haies brise-vent. Institut de technologie agricole de La Pocatière. Mise à jour du cours no. 19.

21. Vigiak O., Sterk G., Warren A., Hagen L. J, 2003. Spatial modeling of wind speed around windbreaks. Catena, 52(3-4), 273-288. 